\title{
Reactivation of unaccusative and unergative verbs in Mandarin
}

\section{Evidence from a cross-modal lexical priming experiment [中文非賓格與非作格的線上跨模組觸發研究]}

\author{
Yowyu Lin [林祐瑜] \\ National Taiwan University [國立臺灣大學]
}

Intransitives can be classified into two subclasses: unaccusative verbs and unergative verbs. According to the Unaccusative Hypothesis, the difference between unaccusatives and unergatives lies in where the single argument is generated in the underlying syntactic structure. Subjects of unaccusative verbs are base-generated in the object position and moved to the subject positions. Subjects of unergative verbs, however, are external and thus are not resulted from arguments moving from the object position. If the Unaccusative Hypothesis is correct, a trace is left at the original place for unaccusative verbs when movement occurs but no trace for unergative verbs. Friedmann et al. (2008) used the cross-modal lexical priming paradigm to examine the Unaccusative Hypothesis but their results could only lend limited support for the Unaccusative Hypothesis. Since the argument of Mandarin unaccusative verbs can occur preverbally and postverbally, it offers us a balanced testing ground to re-examine reactivation during sentence comprehension. Results of the current study lend support for the Unaccusative Hypothesis. When the argument occurred preverbally, a V-shaped line was observed. An inverted V-shaped line was observed when the argument occurred postverbally. For unergative verbs, the line showed a decay of reactivation.

Keywords: unaccusatives, unergatives, cross-modal priming task

關鍵詞：非賓格、非作格、跨模組觸發研究 


\section{Introduction}

One of the major research interests in psycholinguistic studies is to understand how a human parser processes different kinds of displaced elements during language comprehension. Consider a sentence like "Who did the manager hire (trace) after the interview?" This example exemplifies a wh-movement, where the wh-word "who" was moved from the position after hire to the beginning of the sentence. When processing a sentence like this, a human parser needs to maintain a displaced element like "who" until it comes to the gapped position to do the mapping between the filler and gap. Over the years, psycholinguistic studies have employed different methods and paradigms to examine syntactic structures that involve displaced elements like the example above. The current study used a cross-modal priming task to examine Mandarin sentences with different kinds of intransitive verbs, which, according to Perlmutter (1978), can be associated with different underlying syntactic structures with or without movements. This paper will give an introduction to intransitive verbs in English before discussing the advantages of using a cross-modal priming task in examining the differences between different types of intransitive verbs. Then the special properties of Mandarin unaccusatives and unergatives are introduced, followed by the experimental design of the current experiment.

Verbs are traditionally divided into two categories: transitive verbs and intransitive verbs. Transitive verbs require one subject and one or more objects follow the verb. Transitive verbs which take two objects are ditransitive verbs. These two objects are usually referred to as the theme and the recipient. Intransitive verbs, on the contrary, require one subject but no objects. Example (1) illustrates verb transitivity.

(1) a. Transitive verb

John ate an apple.

b. Ditransitive verb

John gave Peter a book.

John gave a book to Peter.

c. Intransitive verb

John ran.

In Example (1a), the transitive verb "ate" takes two arguments, i.e., "John" and "apple," with one occurring preverbally and one postverbally. In Example (1b), the ditransitive verb "gave" takes three arguments, i.e., "John," "Peter" and "book," with one occurring preverbally and two occurring postverbally. In Example (1c), the intransitive verb takes only one argument, which occurs preverbally. Notice that not all verbs have a clear-cut category. Many verbs actually display transitivity 
alternations: They can be either transitive verbs or intransitive verbs, as shown in Example (2).

(2) a. The careless man broke the window.

b. The window broke.

The verb used in Example (2) is "break," which can be used transitively and intransitively. Intransitive verbs, even though they take only one argument, can have very different linguistic properties. For example, Perlmutter's Unaccusative Hypothesis (1978) claimed that intransitive verbs can be divided into two subcategories: unaccusative verbs and unergative verbs, each associated with different syntactic and semantic configurations. Example (3) illustrates these two types of verbs.

(3) a. Unergative verbs jump, dance, fly, speak, paint, run, laugh, etc.

b. Unaccusative verbs break, sink, happen, appear, vanish, etc.

Their differences can be further exemplified by the following sentences.

(4) a. Unergative verb

The girl jumped.

b. Unaccusative verb

The window broke.

Linearly and superficially, these two sentences consist of a noun phrase and an intransitive verb. A close look at these two sentences, however, reveals that "the girl" has volition and did the jumping but the window does not have volition and was actually broken by someone else. Similar examples with volition in unergative verbs and without volition in unaccusative verbs are given in Example (5).

(5) a. Unergative verbs

The girl ran.

The girl laughed.

The girl flew.

b. Unaccusative verbs

The window broke.

The ice melted.

The ship sank.

The noun phrases in (5a) can be characterized by possessing volition and those in (5b) can be characterized by a lack of volition. However, even these subclasses are not homogeneous. Each subclass can be further divided by other semantic features. According to Perlmutter (1978), unergative verbs are associated with 
"active" or "activity" clauses, which can be further distinguished by whether they are "volitional acts" or "involuntary body functions." Unergative verbs that involve volitional acts include work, play and speak. Those that involve body functions include cough, sneeze and sleep. Unaccusative verbs are associated with an even larger semantic domain, including "predicates expressed by adjectives in English," "predicates whose initial nuclear term is semantically a patient," "predicates of existing and happening," "non-voluntary emission of stimuli that impinge on the senses (light, noise, smell, etc.)," "aspectual predicates" and "duratives."

In addition to the above-mentioned subclasses, there is another way to characterize unaccusative verbs: whether or not they have transitive counterparts. For example, "break" can be used either as a transitive or intransitive verb. As a transitive verb, "break" can be used in a sentence such as "He broke the glass." In this example, the noun phrase "the glass" is the object of the causativetransitive verb "broke." As an intransitive verb, "break" can be used in a sentence such as "The glass broke." In this example, "the glass" is the subject of the sentence. Because of this attribute, unaccusative verbs with transitive counterparts are termed "alternating unaccusative verbs." On the contrary, unaccusative verbs without transitive counterparts are termed "non-alternating unaccusative verbs." For example, "appear" can only be used as an intransitive verb, not as a transitive verb. Sentences like "The man appeared the house" are therefore ungrammatical. Examples of alternating unaccusative verbs and non-alternating unaccusative verbs are given below.

(6) a. Alternating unaccusative verbs

bounce, break, change, drop, dry, freeze, grow, melt, roll, stop, continue, increase, decrease, improve, derive, etc.

b. Non-alternating unaccusative verbs appear, depart, die, disappear, exist, emerge, vanish, remain, bloom, happen, occur, etc.

Example (6) shows that non-alternating unaccusative verbs usually denote existence and appearance while alternating unaccusative verbs are usually not associated with these attributes. Researchers like Levin \& Hovav (1995) assumed that alternating unaccusative verbs were causative verbs, implying that alternating unaccusative verbs were derived from their causative counterpart verbs. But since non-alternating unaccusative verbs do not have transitive counterparts, these verbs are not derived from transitive verbs.

In addition to these differences between unaccusative verbs and unergative verbs, the Unaccusative Hypothesis further claims that the initial noun phrase is actually generated at different positions in the underlying linguistic structures. This is illustrated by the following examples. 
(7) Syntactic structure of unergative, unaccusative and transitive verbs

a. Unergative verbs NP [ $\left.{ }_{V P} \mathrm{~V}\right]$

b. Unaccusative verbs [vP V NP]

c. Transitive verbs NP [V NP]

As shown in (7), two logical arguments exist for a transitive verb: one external argument and one internal argument. The internal argument combines with the verb to form a predicate, which then combines with the external argument to form a proposition. The external argument serves as the subject of a sentence while the internal argument serves as its object. However, only one argument exists for unergative and unaccusative verbs and they differ in whether this single argument is external or internal. Unergatives have an external or preverbal argument and lack an internal argument. This external argument usually gets a thematic agent role. Unaccusatives, on the contrary, have an internal or postverbal argument in the base structure but not an external argument. This internal argument bears a thematic patient role. Since an unaccusative verb with an internal argument but without an external argument cannot assign accusative case and a verb failing to assign accusative case cannot theta-mark an external argument, in order for the internal argument to get case, this internal argument has to be moved to the external position. The word order thus resembles that of unergative verbs.

(8) a. Unergative verb

"The girl ran."

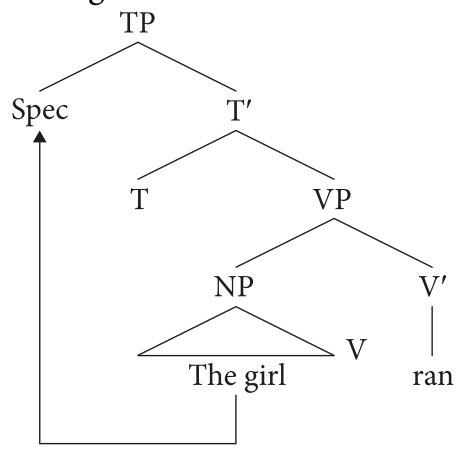


b. Unaccusative verb

"The window broke."

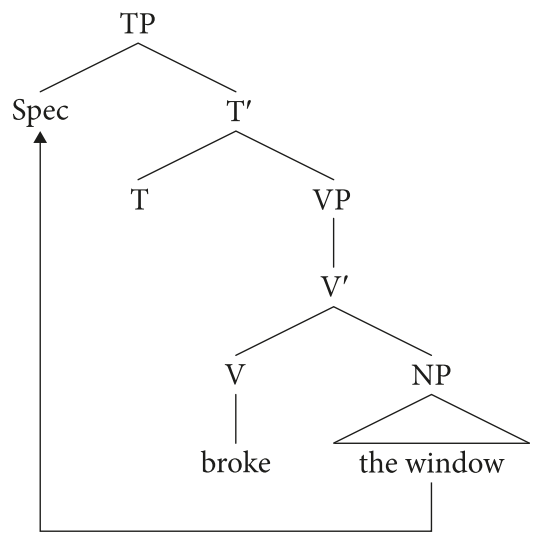

Example (8) illustrates how the surface structures of unergatives and unaccusatives originally differ but resemble each other in structure after movement. When "the window" is moved to the specifier position, a trace is left in the original position. However, no such trace exists for unergatives since no movement is involved.

\section{Unaccusative and unergative verbs in Mandarin}

The unaccusative-unergative distinction also exists in Mandarin, with similarities and differences. While some languages, such as Dutch (Zaenen 1993), mark unaccusatives and unergatives as morphologically different, others, such as Mandarin, distinguish them with word order. With respect to similarities, Mandarin, a language with fewer case markers, generally marks case positionally, usually placing subjects in clause-initial position and objects after the verb (Aldridge 2015). The following examples illustrate this point.

(9) a. Lisi mai le na liang che.

Lisi buy ASP DEM CL Car

'Lisi bought that car.'

b. Wangwu lai le.

Wangwu come AsP

'Wangwu has come.'

In addition, C.R. Huang (1993:19) stated that “...unaccusative verbs in Mandarin are those nonpassive verbs whose only arguments have the thematic roles of either THEME/PATIENT or any of the lower roles." 
With respect to differences, “...there is abundant evidence indicating that the single argument of an unaccusative verb in Chinese can remain in object position at PF" (Yuan 1999: 279). To be more specific, while the argument precedes the unaccusative verbs in English, Mandarin unaccusative verbs allow the argument to occupy either the preverbal position or the postverbal position (Zhou 1990, $\mathrm{Li}$ 2012, Aldridge 2015). The following examples taken from Yuan (1999) illustrate this point.

(10) a. Mandarin unaccusative verbs: Preverbal argument

Wǔ gè xué sheng zǒu le.

five CL student leave le

'Five students left.'

b. Mandarin unaccusative verbs: Postverbal argument

Zǒu le wǔ gè xué sheng.

leave le five cL student

'Five students left.'

According to Yuan (1999), English and Mandarin thus differ in the scope of syntactic structure. Unlike the internal argument of an unaccusative verb in English which must be moved to the preverbal position, the internal argument in Mandarin can actually stay in situ, as long as they are indefinite. Note that even though the single argument can exist either preverbally and postverbally in Example (10), there are some restrictions. First, the argument noun phrase cannot be definite. As shown in the following example, a definite noun phrase following the unaccusative verb will lead to ungrammaticality in Mandarin.

(11) Unaccusative verb: Postverbal argument with a definite noun phrase

*Zǒu le nà wǔ gè xué sheng.

leave le that five cL student

'Five student left.'

The second restriction concerns pronouns and personal names, which for unaccusative verbs are restricted to the preverbal position (Aldridge 2015).

(12) Pronoun and personal names as arguments

a. Tā lái le.

he come ASP

'He has come.'

b. *Lái le tā.

come asp he

'He has come.' 


\section{c. Mǎ-lì lái le. Mary come AsP 'Mary has come.' \\ d. *Lái le Mă-lì. come Asp Mary 'Mary has come.'}

Mandarin unergative verbs, however, only allow their arguments to appear preverbally, no matter whether they are definite NPs or indefinite NPs. The following examples illustrate this point.

(13) a. Unergative verb in Mandarin: Indefinite NP in preverbal position Wǔ gè xué shēng zài zhuō shàng tiào.

five CL student on desk top jump

'Five students are jumping on the desk top.'

b. Unergative verb in Mandarin: Indefinite NP in postverbal argument

*Zài zhuō shàng tiào wǔ gè xué sheng.

on desk top jump five CL student

'Five students are jumping on the desk top.'

c. Unergative verb in Mandarin: Definite NP in preverbal position

Nà wǔ gè xué shēng zài zhuō shàng tiào.

that five CL student on desk top jump

'Those five students are jumping on the desk top.'

d. Unergative verb in Mandarin: Postverbal argument

*Zài zhuō shàng tiào nà wǔ gè xué sheng.

on desk top jump that five CL student

'Those five students are jumping on the desk top.'

According to Yuan (1999), "jump" is a Mandarin unergative verb, which denotes a controlled motional process, but not directed motion, nor change of location, the latter two of which are attributes of unaccusative verbs. However, Indo-European languages such as German, Dutch and Italian have consistently shown that when combined with directed motion phrases, these unergative verbs can become unaccusative verbs. In these languages, unaccusative verbs tend to go with the auxiliary be while unergative verbs tend to go with have. Studies have shown that native speakers of Dutch, Italian and German select the auxiliary be when their unergative verbs are modified with directed motion phrases. The transformation from unergative verbs to unaccusative verbs can also be observed in Mandarin. When a motional unergative verb like "jump" is followed by a directional phrase, it transforms from an unergative verb to an unaccusative verb. 
(14) Unergative verb "jump" followed by a directional phrase

Zhuō shàng tiào xià lái wǔ gè xué sheng.

desk top jump down five CL student

'Five students are jumping down from the desk top.'

As indicated by this example, when directional phrases like "xialai" follow unergative verbs like "jump," they can change the previous ungrammatical sentence into a grammatical one. In addition to a structural diagnosis, other diagnostics include lexical causativization (C.-T. Huang 1989) and semantic features such as telicity (Sorace 1995, Paul et al. 2020).

Ever since the Unaccusative Hypothesis was proposed, researchers have been examining its validity. For example, Sorace and her collaborators (Sorace 1993a, 1993b, 2000, Sorace \& Shomura 2001, Sorace \& Keller 2005) examined unaccusative verbs and unergative verbs in Indo-European languages like Italian, German, Dutch and French and found that unaccusative verbs and unergative verbs seem to select different auxiliaries, i.e., "be" or "have." However, not all unaccusatives and unergatives behave in the same way. Constraints and variations exist among different categories within both unaccusatives or unergatives. That is, while some verbs tend to be invariant with respect to auxiliary selection, others exhibit variation, regressing between choosing "be" and "have." Sorace proposed a Split Intransitivity Hierarchy, which claims that unaccusative verbs and unergative verbs lie between the two extremes of a hierarchy. The two extremes that can be used to represent unaccusative verbs and unergative verbs are "change of location" and "controlled nonmotional process," respectively. The other points along this hierarchy include "change of condition," "appearance," "continuation of preexisting condition," "existence," "uncontrolled process" and "controlled motional process." The Split Intransitivity Hierarchy proposes that the two extremes, or two cores, are invariant with respect to auxiliary selection. The farther away a category is from the core, the more likely it will accept both auxiliaries.

Experimentally, researchers have examined the Unaccusative Hypothesis using cross-modal priming or lexical decision tasks (Nicol 1988, Nicol \& Swinney 1989, Osterhout \& Swinney 1993, Nicol, Fodor \& Swinney 1994, Fadlon 2016, Chng, Yap \& Goh 2019). As the name suggests, a cross-modal lexical decision task involves using both modals during sentence comprehension. Typically, it involves using visual and audio presentations of stimuli. During an experiment, participants sit in front of a computer and listen to a sequence of words through headphones. While they listen to the sentence stimuli, a target word, or a probe, is presented on the computer screen, and participants are asked to judge whether this target is a word or not. When the target is a real word, it can be either seman- 
tically related to a noun phrase in the sentence that participants hear or semantically unrelated to this noun phrase. The priming effect occurs when there is facilitation of the responses when the target is semantically related to the noun phrase in the sentence stimuli. The cross-modal lexical decision task is useful in detecting reactivation for either explicit or implicit antecedents in syntactic structures such as wh-trace (Swinney et al. 1988), NP-trace (Bever \& McElree 1988), overt anaphors and pronouns (Nicol 1988) (see Nicol \& Swinney 1989 for a review). Explicit antecedents refer to cases such as pronoun resolution, where explicit pronouns such as "he," "she," "it" or "they," can refer to a previously encountered noun phrase or antecedent. For example, Nicol (1988) examined reactivation patterns in sentences containing explicit anaphors. The sentences used were like the following:

(15) a. The boxer told the skier that the doctor ${ }_{i}$ for the team would blame himself for the recent injury.

b. The boxer ${ }_{i}$ told the skier ${ }_{i}$ that the doctor for the team would blame him ${ }_{i}$ for the recent injury.

The two sentences in (15) are almost identical except for the word after "blame." In (15a), "himself" could refer to "doctor" but not "boxer" and "skier." However, in (15b), "him" could refer to "boxer" or "skier" but not "doctor." In Example (15a), immediately after the anaphor, the priming effect was found for "doctor" but not for "boxer" or "skier." On the contrary, in Example (15b), priming was found for both "boxer" and "skier" but not for "doctor." Similar results using the crossmodal lexical priming paradigm can be found in Dell, McKoon \& Ratcliff (1983). In their study, experimental sentences containing critical words were embedded in a paragraph, which consisted of four sentences. The first three sentences were "(Sentence 1) A burglar surveyed the garage set back from the street; (Sentence 2) Several milk bottles were piled at the curb; (Sentence 3) The banker and her husband were on vacation." There were two versions of Sentence 4, one with an anaphor ("The criminal slipped away from the streetlamp.") and one without ("A cat slipped away from the streetlamp."). In the first version, the first noun "the criminal" referred to the targeted critical word "burglar," thus, according to Dell, McKoon \& Ratcliff (1983), forming an anaphoric reference. However, an anaphoric reference cannot be established in the second version. Note that except for the very first noun phrase, everything was the same in the two versions of the fourth sentence. The results showed that processing is facilitated when the anaphor can be referred to the antecedent in the previous discourse. In other words, response times were more rapid when the fourth sentence contained an anaphor. Dell, McKoon \& Ratcliff's study also indicates that antecedent activation works not only in sentences but also in contexts. 
Unlike explicit antecedent activation shown in previous studies, implicit antecedent reactivation refers to filler-gap dependency during sentence comprehension. When an element is moved out of its original position, a trace is left. The cross-modal lexical priming paradigm is also useful in examining whether facilitation or inhibition occurs at the trace and the positions that follow. For example, Swinney et al. (1988) examined reactivation of wh-traces embedded in relative clauses. The stimuli that they used were as follows:

(16) The policeman saw the boy ${ }_{i}$ that the crowd at the party [probe point 1] accused $\underline{t i}$ [probe point 2 ] of the [probe point 3 ] crime.

The subscript $t$ stands for trace, which is coindexed with boy in the sentence since the boy was being accused of a crime by the crowd. To examine reactivation of the antecedent, i.e., the boy, three probe points, the bracketed parts in the sentence, were used. The first probe point occurs before the trace, the second right after the trace position and the third point occurs a couple of words after the trace position. During these probe points, visual word and non-word targets are presented on the computer screen to prompt a response. The purpose of their experiment was to investigate whether priming can be induced by comparing the response time differences between semantically related targets and semantically unrelated targets. Priming occurs when participants spend significantly less time on targets, which are semantically related to the antecedents that they have heard previously. Their results show processing facilitation at probe points 2 and 3 but not probe point 1 . This indicates a priming effect resulted from reactivation of the antecedent at these two positions.

Reactivation of the antecedent along the downstream of sentences has been found by many studies using other syntactic constructions (Nicol \& Swinney 1989, Hickok 1993, Osterhout \& Swinney 1993, Nicol, Fodor \& Swinney 1994). Love \& Swinney (1996), for example, examined the activation of ambiguous words embedded in context-biased object relative clauses.

(17) The professor insisted that the exam be completed in ink, so Jimmy used the new pen [probe point 1] that his mother-in-law recently [probe point 2] purchased $\underline{t i}$ [probe point 3 ] because the multiple colors allowed for more creativity.

Lexically ambiguous words have at least two meanings: one dominant and the other secondary. These words were then embedded in the target sentence, with their meaning biased toward the dominant meanings. In addition, these words served as fillers for the gap, represented as $t i$ in the above example. Probe points were the positions where the visual probe occurred on the screen when subjects listened to experimental sentences. The probes in this example are: (1) Primary 
meaning: related=PENCIL; (2) Primary meaning: control=JACKET; (3) Secondary meaning: related=JAIL; Secondary meaning: control=TALE. The subjects were told to listen to the sentences presented via headphones and when they saw a word appear on the screen they had to name it as quickly as they could. Love \& Swinney (1996) found immediate reactivation of structurally marked antecedent fillers once a structural gap was licensed during language processing. In addition, they also found that at probe position 1, all meanings of lexically ambiguous words are activated. This activation decays at probe position 2 , while at probe position 3, only the context-relevant meaning is activated.

Moreover, Friedmann et al. (2008) used a cross-modal lexical priming paradigm to examine online processing of sentences containing unaccusative and unergative verbs. The unaccusative verbs they used included alternating and nonalternating unaccusative verbs. The stimuli were as follows:

(18) a. Nonalternating unaccusative

The tailor [probe point 1] from East Orange, New Jersey, mysteriously disappeared $\underline{t}$ [probe point 2] when it was [probe point 3] time to adjust the tuxedos and dresses for the participants in the wedding party.

b. Alternating unaccusative

The table [probe point 1] in the basement of the old house finally dried $\underline{t} i$ [probe point 2] after the leaking [probe point 3] window was sealed a month ago.

c. Unergative

The surgeon [probe point 1] with a brown felt fedora hat and matching coat eagerly smiled $\underline{t}$ [probe point 2 ] when the beautiful [probe point 3 ] actress walked down the corridor to exam room three.

As seen in Example (12), three probe points were used in each sentence. The first probe point immediately follows the first noun phrase. The second probe point follows the target verb, i.e., alternating unaccusative verb, non-alternating unaccusative verb or unergative verb. The third probe point is several words away from probe point 2. This ensures that enough time passes between the antecedent and the trace. According to the Unaccusative Hypothesis, subjects in sentences containing unaccusative verbs are generated in object positions and are then raised to subject positions. However, subjects in sentences containing unergative verbs are base-generated in subject positions and thus no movement is required. If the Unaccusative Hypothesis is correct, a quadratic line should be observed across the three positions for unaccusative verbs. According to Friedmann et al., a quadratic line indicates a decay in reactivation and then a reactivation of the antecedent at the later position if subjects detect a filler-gap dependency in the sentence. However, for unergative verbs a linear decrease of the priming effect 
across the three probe positions should be observed since there is no reactivation of the first noun phrase.

Friedmann et al.'s study showed a quadratic line for non-alternating unaccusative verbs, finding a drop of mean priming effect at the second position and then an increase at the third position. This indicates a reactivation due to priming. Notice that the reactivation did not occur at the trace position. They reasoned that it was because no overt word, such as a relative pronoun or a complementizer, was present to signal the presence of the upcoming gap or trace. In processing sentences containing unaccusative verbs and unergative verbs, these verbs are the only source that can tell comprehenders of an upcoming gap in the structure. Therefore, the results show a decay of the activation in the time course at the second probe position and a reactivation at probe position 3 .

For alternating unaccusative verbs, however, Friedmann et al. did not observe faster reactions to the probe at the second and the third positions, indicating that there was no reactivation at all. Further analysis of these alternating verbs revealed that verbs such as dried, sank, opened, bounced, froze and grew behaved like non-alternating unaccusative verbs, with decay at probe position 2 and reactivation at probe position 3. However, alternating verbs like cracked, swung and shut behaved like unergative verbs, with decay from probe position 1 all the way to probe position 3 . Friedmann et al. hypothesized that the different behavior of these alternating verbs could be ascribed to the fact that since they had transitive counterparts, the parser might initially parse them as transitive verbs and therefore no reactivation could be induced. For unergative verbs, there was a linear decreasing line, showing no reactivation at position 2 and position 3. Reactivation of antecedent noun phrases has been found in different syntactic structures in many studies as well (Tanenhaus, Stowe \& Carlson 1985, Bever \& McElree 1988, Bever \& Sanz 1997).

Taken together, results that support the Unaccusative Hypothesis in Friedmann et al.s study came solely from reactivation at the third position in nonalternating unaccusative verbs. Nevertheless, given that both unergative and alternating unaccusative verbs showed linear decay lines, finding only reactivation at the third position in non-alternating unaccusative verbs might not be convincing enough to support reactivation of antecedents. Since Friedmann et al's results were far from conclusive, the current study re-examined reactivation of alternating and non-alternating unaccusatives and unergatives in Mandarin, whose special property mentioned above offers a balanced testing ground for us to observe lexical priming effect.

To date, using cross-modal priming paradigms to examine the unaccusativeunergative distinction has been mostly limited to Indo-European languages. Most studies examining Mandarin unaccusatives and unergatives have focused on the- 
oretical aspects (C.-T. Huang 1989, C. R. Huang 1993, C.-T. Huang 2006, Hu \& Pan 2008, Paul, Lu \& Lee 2020), overpassivization of second language learners (Yuan 1999, Ju 2000, Oshita 2001, Chung 2014, Kim 2014, Kim, Choi \& Kang 2016) and archaic Chinese (Aldridge 2015). To the best of my knowledge, no study has been done to investigate the reactivation of antecedents in unaccusatives and unergatives in Mandarin. Given the unique structure of Mandarin unaccusative verbs and unergative verbs, they can provide a more balanced and unconfounded testing ground for further examining reactivation of antecedents during sentence comprehension. In addition, they allow us to re-examine the validity of Perlmutter's Unaccusative Hypothesis. Recall that in Examples (7) and (8), the difference between unaccusatives and unergatives lies in where the argument originates. The arguments of unaccusatives originate in the object position and are moved to the beginning of the sentence, while no movement is associated with the arguments of unergative verbs. Given that Mandarin unaccusatives' argument can occur preverbally and postverbally, there exist different kinds of filler-gap dependencies. A trace is left when the argument is moved from the object position to the subject position. In this circumstance, filler-gap mapping is bound to happen when the argument occurs preverbally. However, when the argument occurs postverbally, no filler-gap mapping is observed. Examples are given below.

(19) Syntactic structure of Mandarin unaccusative verbs with arguments occurring preverbally and postverbally

a. Unaccusative verbs with verbs occurring preverbally

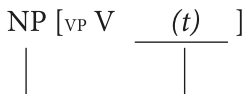

b. Unaccusative verbs with verbs occurring postverbally $[\mathrm{VP}$ V NP]

\section{Current experiment}

As stated in the previous section, the fact that the argument can occur preverbally and postverbally offers us a further chance to tease apart the difference between unaccusative and unergative verbs. If the Unaccusative Hypothesis is correct in that a trace is left when the argument is moved from the object position to the subject position, we should be able to observe reactivation when the argument occurs preverbally. That is, a priming effect should occur not only at the first position, but also at the position where filler-gap mapping is required and possibly at subsequent positions. On the contrary, when the argument occurs postverbally, no filler-gap mapping is required and thus no reacti- 
vation, leading to a decay in the activation, should be observed. Accordingly, the lines between preverbal and postverbal conditions should be very different. It is of interest to see whether similar reactivation conditions can be observed in both non-alternating and alternating unaccusatives. Finally, since the Unaccusative Hypothesis assumes no movement of the argument in Mandarin unergative verbs, no trace should be found at the position after the verb and therefore no reactivation should be observed. In other words, we would be able to observe a linear decay of the priming effect over the probe positions.

\section{Methodologies}

Sixty native speakers of Mandarin (mean age: 20.6) were recruited to participate in this study. They were all college students in Taiwan. Before the experiment started, they filled out a background questionnaire. The participants all had normal or corrected-to-normal vision and hearing. None of them had reading disorders or neurological injuries. In addition, none of them had taken linguisticsrelated courses.

Ten verbs were chosen for each type of intransitive verb: non-alternating unaccusatives, alternating unaccusatives and unergatives. The same ten verbs were used in preverbal and postverbal arguments to allow us to directly compare the results. Note that even though the preverbal and postverbal arguments used the same ten verbs, different sentences were constructed so that the responses did not come from repetition. The verbs were mostly taken from Friedmann et al's stimuli list, which lists eighteen verbs for each kind of intransitive verb. However, some verbs were eliminated for the following reasons. First, some of these eighteen verbs were repetitions. Second, some of the verbs might result in the same Mandarin translation, e.g., vanish vs. disappear. Third, Mandarin translations of some of the verbs may seem to contain an object. For example, one possible translation of "wave" in Mandarin is "hū shǒu" and instead of treating the whole chunk as an intransitive verb, it's possible to argue that "hand" is the object in this phrasal chunk. Verbs like this were eliminated to prevent ambiguities.

Since the current experiment aimed to examine the reactivation of noun phrases at different probe positions and since Mandarin characters are monosyllables, to allow more time to pass so that reactivation and decay may happen, the sentence stimuli were "padded" with extra adverbial time phrases or clauses. In Friedmann et al.s study, there were only three probe positions. However, given that only the third position in non-alternating unaccusatives elicited reactivation, it is of valid concern whether the priming effect came from reactivation or something else. To circumvent this problem, four probe points were embedded in the 
sentence stimuli in the current study. It was crucial to employ four probe positions since the argument of Mandarin unaccusative verbs can appear both preverbally and postverbally. If the argument occurred postverbally and there were only three probe positions, it would be hard for reactivation and decay to be exhibited.

For the sentence stimuli, the first probe position was placed right after the argument when it occurred preverbally. For postverbal argument, the first probe position occurred at around the same position in the sentence. The second probe position was placed at the trace position for preverbal argument and at the argument position when it appeared at the postverbal position. The length between each first and second probe position was around eight Mandarin characters. The third probe position was placed around ten characters after the second probe. The fourth position was also manually set to be around seven or eight characters after the third probe.

(20) Sentential stimuli in the current experiment

a. Non-alternating unaccusative verb: Preverbal argument

Sān gè xué shēng $i$ [probe position 1] dēng shān tú zhōng tú rán xiāo shī $t i$ [probe position 2] zhī hòu quán xiào tóng xué dū fèi cháng zhèn jīng [probe position 3] bìng fēn biǎo dá qiáng liè de [probe position 4] guān qiè.

'After three students disappeared while mountain climbing, all their classmates in school were shocked and expressed their strong concern.'

b. Non-alternating unaccusative verb: Postverbal argument Shàng gè xīng qí [probe position 1] shān shàng xiāo shī sān gè lü kè [probe position 2] zhī hòu tóng tuán péng yǒu dū fēi cháng yà yì [probe position 3] bìng fēn biǎo dá qiáng liè de [probe position 4] guān qiè.

'After three tourists got lost in the mountains last week, all their teammates were shocked and expressed their concern.'

c. Alternating unaccusative verb: Preverbal argument

Yī ge yī shēng $i$ [probe position 1 ] shàng gè yuè zhōng tú rán bān zǒu $t i$ [probe position 2] zhī hòu quán bù cūn mín dū fēi cháng nán guò [probe position 3 ] bìng cháng găn dào qiáng liè de [probe position 4] yōu lü.

'After a doctor suddenly moved away last month, the villagers were all very sad and felt terribly worried.'

d. Alternating unaccusative verb: Postverbal argument

Shàng gè xīng qí [probe position 1] tú rán bān zǒu yī ge yī shēng [probe position 2] zhī hòu cūn mín dū fēi cháng nán guò [probe position 3] bìng cháng găn dào qiáng liè de [probe position 4] yōu lü.

'After a doctor suddenly moved away, the villagers were all very sad and felt terribly worried.' 


\section{e. Unergative verb}

Nián qīng jǐng chá [probe position 1] zhăo dào zuàn jiè zhī hòu xiào liǎo [probe position 2] jiā rén quán bù dū fēi cháng xīng fèn [probe position 3] bìng fēn biǎo dá chéng zhì de [probe position 4] xiè yì.

'The young cop smiled after finding the lost diamond. All the staff were excited and expressed their deep gratitude.'

Ten sentence stimuli were created for each condition: ten sentences for nonalternating unaccusative verbs with the argument occurring at the preverbal position, ten sentences for non-alternating unaccusative verbs with the argument occurring at the postverbal position, ten sentences for alternating unaccusative verbs with the argument occurring at the preverbal position, ten sentences for alternating unaccusative verbs with the argument occurring at the postverbal position, and finally ten sentences for unergative verbs. In total, there were 50 sentence stimuli and 50 filler sentences. Transitive verbs were used in these filler sentences and they did not contain any intransitive verbs at all. The sentence stimuli and the fillers were pseudorandomized so that no two sentences of the same type appeared in a row. Finally, three lists were created and twenty subjects randomly assigned to each one.

Note that even though arguments can occur preverbally and postverbally in Mandarin unaccusative verbs, it is possible that preverbal and postverbal structures might sound different to Mandarin native speakers. To rule out this possibility, a norming study was conducted. Fifteen Mandarin native speakers were recruited to rate the naturalness of the experimental stimuli by using a 5-point Likert scale where "1" stood for "Very Unnatural," "2" stood for "Unnatural," "3" stood for "Acceptable," " 4 " stood for "Natural" and " 5 " stood for "Very Natural." One of the alternating unaccusative experimental sentences had an average score of under 4 points and was therefore replaced. Finally, the average score for each type of stimuli was as follows: Non-alternating unaccusative with preverbal argument: $M=4.45$; Non-alternating unaccusative with postverbal argument: $M=4.3$; Alternating unaccusative with preverbal argument: $M=4.48$; Alternating unaccusative with postverbal argument: $M=4.32$; Unergative: $M=4.4$.

During the experiment, the experimental stimuli were presented to the participants over headphones. The participants were asked to focus on the aural presentation of the stimuli. As the participants listened to the sentences, the computer screen showed Mandarin phrases (two Mandarin characters) at each probe position. The participants needed to decide whether the phrases were real phrases or non-phrases in Mandarin. The two-character real Mandarin phrases were either semantically related to the target noun phrase, i.e., "students," "doctor," "policeman" and "tourist" in Example (19), or semantically unrelated. For semantically related probes, twenty students who did not participate in the experiment were 
recruited and were given a list of all the target noun phrases. They were told to write down close semantic associates of these target noun phrases. The semantic associate that was given most frequently was selected as the related probe. For the unrelated probes, since previous studies examining pronoun cases found reactivation for multiple referents (Nicol \& Osterhout 1988), care was taken to use words not related to any noun phrase in the sentence stimuli. For example, in (19a), for the target noun phrase "student," an example of a semantically related noun phrase would be "teacher" and an example of a semantically unrelated word is "immigrant." With respect to non-phrases in Mandarin, a reversal of Mandarin phrases was used. For example, "zhuō zì" was " $z \grave{\imath} z h u \bar{o}$." The participants were instructed to respond "No" when they saw phrases that were non-phrases. These visual targets, counterbalanced across the entire experiment, appeared at four positions while participants listened to sentential stimuli.

\section{Results}

The main issue investigated by the current study was whether a priming effect could be observed or subject noun phrases could be reactivated after alternating unaccusative verbs, non-alternating unaccusative verbs and unergative verbs. Priming patterns were examined at the four target positions. A mean priming effect was calculated by comparing the response time between related Mandarin probes and unrelated Mandarin controls. Statistical analysis across all the verb types, positions, subjects and items revealed that there was a main effect of relatedness $(F(1,7998)=1221.318, p<.00)$ and this was also true for separate subject and item analyses $(p<.00)$ The participants spent significantly less time responding to related probes (659.9 $\mathrm{ms}$ ) than unrelated probes (701 $\mathrm{ms})$.

Since our main interest was to see whether reactivation occurred at some of the later positions or whether a linear decrease occurred following the initial position, a trend analysis was also performed. Note that a significant quadratic trend means that the line shows concavity, bending either upward or downward. A cubic trend would indicate that there were two inflection points, meaning that the line changed direction twice. If reactivation occurred, we would be able to observe at least a quadratic trend or even a cubic trend. However, if no reactivation occurred, a linear decrease would be observed. The following paragraphs present the results of the trend analyses.

Figure 1 presents the results of non-alternating unaccusative verbs with arguments occurring at preverbal and postverbal positions. For non-alternating unaccusative verbs with the argument occurring at preverbal positions, there was a main effect of position (subject analysis: $F(3,57)=10.85, p<.00$; item analysis: 


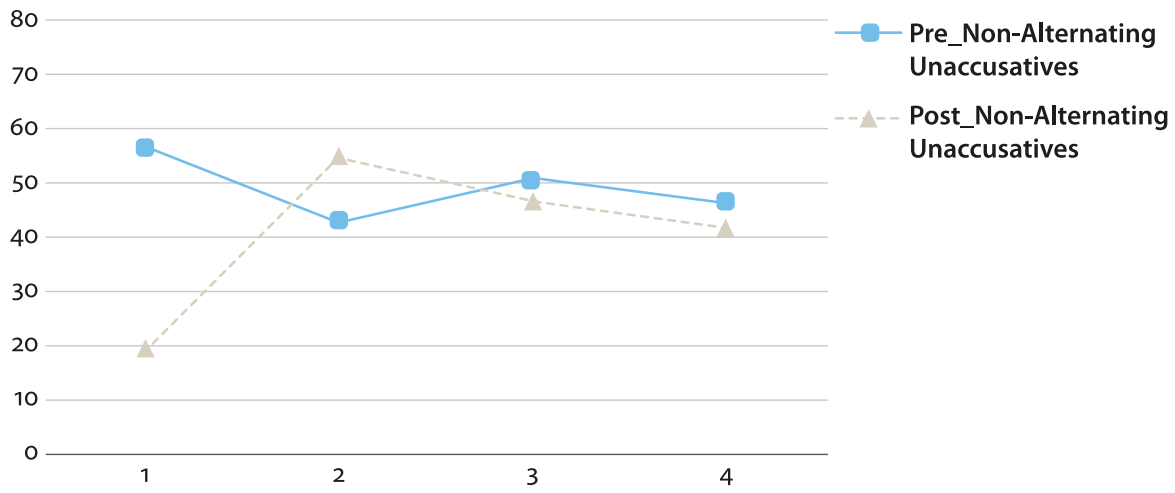

Figure 1. Mean priming effect between preverbal and postverbal positions in nonalternating unaccusative verbs

$F(3,27)=5.97, p<.01)$. The trend analysis revealed a significant quadratic trend (subject analysis: $F(1,19)=7.17, p<.05$; item analysis: $F(1,9)=8.57, p<.05)$ and a significant cubic trend (subject analysis: $F(1,19)=17.84, p<.00$; item analysis: $F(1,9)=13.72, p<.01)$. The quadratic and cubic trends are manifested by a decrease from position 1 to position 2, then an increase from position 2 to position 3 . This indicates a reactivation of the non-alternating unaccusative verbs. Note that if there were no mean priming effect, a linear decay of activation would be observed. Instead of dropping linearly, the line goes up at the third position and then drops a little at the fourth position. Note that, like the results in Friedmann et al.s study, reactivation was not found at the second position where the filler and the gap were supposed to be mapped. One possible reason is that no obvious whwords or relative pronouns were there to provide the parser with a signal to search for a gap immediately. Further discussion is offered in the discussion section.

For the non-alternating unaccusative verbs with arguments appearing postverbally, there was no filler-gap dependency at the second position. The reactivation at the second position was because of the postverbal argument. There was a main effect of position (subject analysis: $F(3,57)=27.81, p<.00$; item analysis: $F(3,27)=45.09, p<.00)$. The trend analysis revealed a significant linear trend (subject analysis: $F(1,19)=12.22, p<.01$; item analysis: $F(1,9)=18.29$, $p<.01$ ), a reliable quadratic trend (subject analysis: $F(1,19)=222.73, p<.00$; item analysis: $F(1,9)=141.73, p<.00$ ) and a reliable cubic trend (subject analysis: $F(1,19)=11.66, p<.01$; item analysis: $F(1,9)=33.72, p<.00)$. This is because there was no priming effect at the first position since the first position was not related to the experimental manipulation at all. A priming effect was found at the second position because the argument in this condition stays in situ. After the second 
position, the line drops a little but it seems that reactivation still lingers at the third and fourth positions.

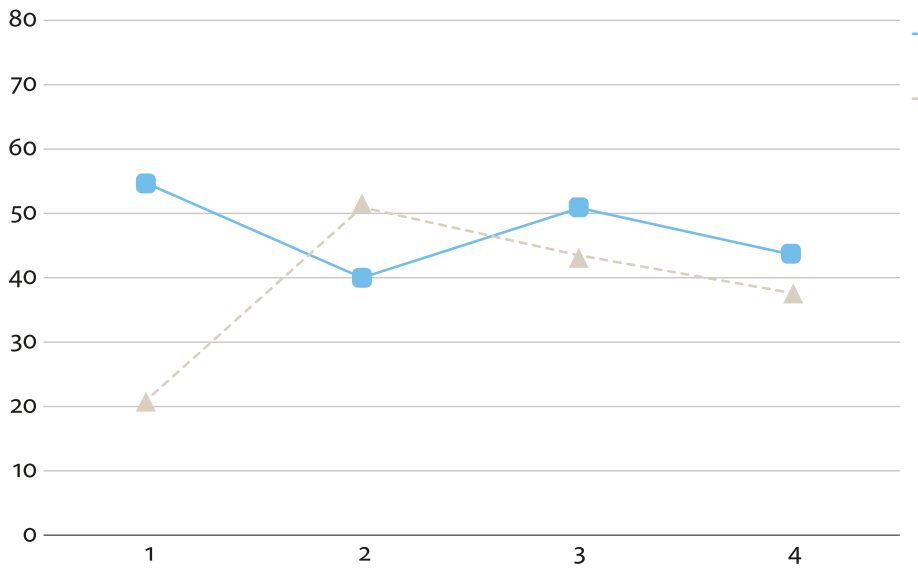

Figure 2. Mean priming effect between preverbal and postverbal positions in alternating unaccusative verbs

Figure 2 presents the results of alternating unaccusative verbs with arguments occurring at preverbal and postverbal positions. For the alternating unaccusative verbs with arguments occurring at preverbal positions, there was a main effect of position (subject analysis: $F(3,57)=26.42, p<.00$; item analysis: $F(3,27)=5.31$, $p<.01$ ). The trend analysis revealed a significant quadratic trend (subject analysis: $\mathrm{F}(1,19)=10.16, p<.01$; item analysis: $p>.05)$ and cubic trend (subject analysis: $F(1,19)=58.44, p<.00$; item analysis: $F(1,9)=5.51, p<.05)$ but not a linear trend $(p>.05)$. In general, there is a V-shaped line from position 1 to position 3 . A priming effect was clear at the first position, which was followed by a decrease of the effect at the second position. Then an increase of the priming effect was observed at the third position, which can be used to indicate reactivation of the antecedent. At position 4, the effect dropped, indicating a decrease of the priming effect at the end of the sentence.

With respect to the alternating unaccusative verbs with arguments occurring postverbally, an inverted $\mathrm{V}$-shaped line was apparent, similar to that observed for the non-alternating unaccusative verbs. There was a main effect of position (subject analysis: $F(3,57)=11.87, p<.00$; item analysis: $F(3,27)=29.53, p<.00)$. The trend analysis revealed a significant linear trend (subject analysis: $F(1,19)=4.8$, $p<.05$; item analysis: $F(1,9)=11.36, p<.01$ ), a reliable quadratic trend (subject analysis: $F(1,19)=39.52, p<.00$; item analysis: $F(1,9)=285.86, p<.00)$ and a reliable cubic trend (subject analysis: $F(1,19)=5.45, \quad p<.05$; item analysis: 
$F(1,9)=10.31, p<.05)$. The priming effect was mainly observed at the second position. This was as expected. After the second position, the line drops at the third position and even more at the fourth position, suggesting linear decay of the reactivation.

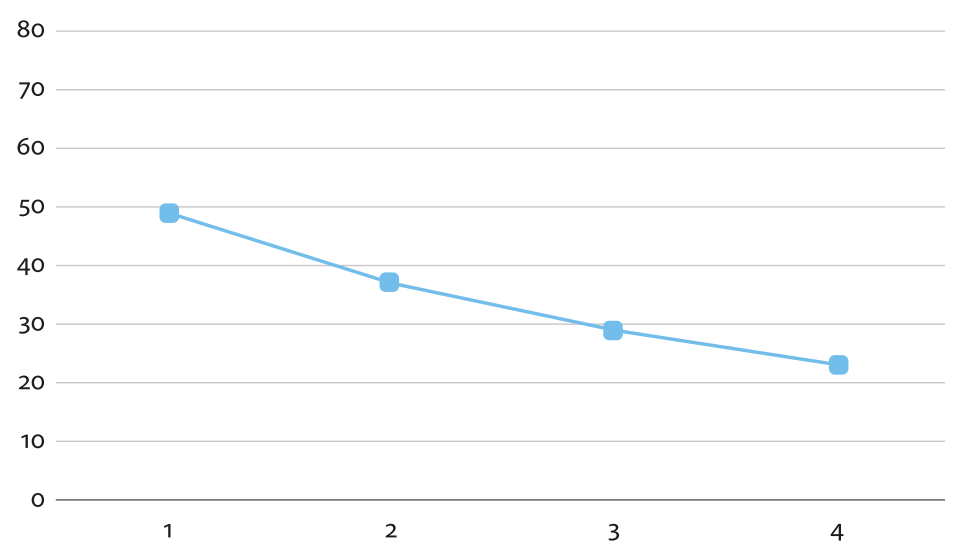

Figure 3. Mean priming effect in unergative verbs

Response times at the four positions for unergative verbs are presented in Figure 3. There was a main effect of position (subject analysis: $F(3,57)=5.81$, $p<.01$; item analysis: $F(3,27)=70.25, p<.00)$. The trend analysis revealed a significant linear trend (subject analysis: $F(1,19)=11.81, p<.01$; item analysis: $F(1,9)=215.08, p<.00)$ but no significant quadratic and cubic trends $(p>.05)$. The four positions of unergative verbs suggest a decay of response times.

Figure 4 presents five conditions across four positions. The five conditions are non-alternating unaccusative verbs with arguments occurring at preverbal and postverbal positions, alternating unaccusative verbs with arguments occurring at preverbal and postverbal positions and unergative verbs. The results of the comparisons across the five sentence structures at all four positions reveal significant differences at each position (Position 1: subject analysis $F(4,95)=23.97, p<.00$; item analysis: $F(4,45)=96.97, p<.00$. Position 2: subject analysis $F(4,95)=5.09$, $p<.01$; item analysis: $F(4,45)=4.59, p<.01$. Position 3 : subject analysis $F(4,95)=8.62, p<.01$; item analysis: $F(4,45)=16.59, p<.00$. Position 4 : subject analysis $F(4,95)=8.33, p<.01$; item analysis: $F(4,45)=10.16, p<.00)$. With respect to multiple comparisons, at position 1 , there are no reliable differences between non-alternating unaccusatives occurring at preverbal positions and alternating unaccusatives occurring at preverbal positions (subject and item analyses: $p>.05$ ) and no reliable differences between two constructions when their arguments occurred postverbally (subject and item analyses: $p>.05$ ). This suggests that when 


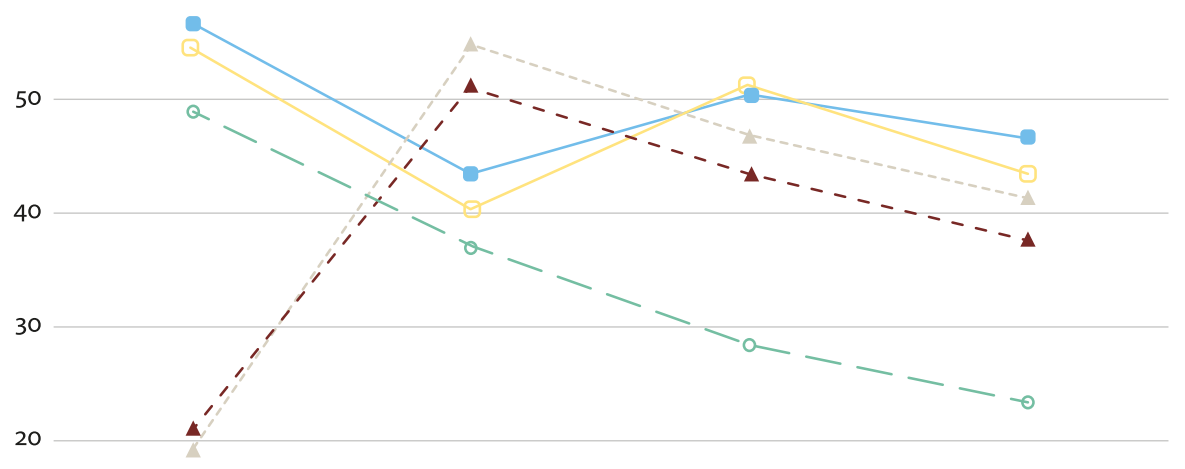

10

0

2

3

4

- - Pre_Non-Alternating Unaccusatives

Post_Non-Alternating Unaccusatives

_- Pre_Alternating Unaccusatives

- _ - Post_Alternating Unaccusatives

$\rightarrow$-Unergatives

Figure 4. Mean priming effect for five different kinds of intransitive verbs

the constructions were similar, i.e., both occurring preverbally or postverbally, similar responses were elicited. The same situation can be observed for position 2 , where there were no reliable differences when the two constructions occurred both preverbally and postverbally (subject and item analyses: $p>.05$ ). Regarding position 3 and 4 , the comparisons did not reach significance (subject and item analyses: $p>.05$ ) with one exception. This was when unergatives were compared with other types (subject and item analyses: $p<.00$ ).

In addition to analyzing the priming effect in their study, Friedmann et al. also examined RT difference between position 2 and position 3 for unrelated probes across different types of intransitive verbs, since this difference could also be used to indicate processing load induced or reduced by the filler-gap dependency. The same analysis was also conducted in this study. There was an average increase of $18 \mathrm{~ms}$ for preverbal non-alternating unaccusatives, $8 \mathrm{~ms}$ for postverbal non-alternating unaccusatives, $13 \mathrm{~ms}$ for preverbal alternating unaccusatives, $6 \mathrm{~ms}$ for postverbal alternating unaccusatives and $5 \mathrm{~ms}$ for unergatives. However, one-way ANOVA did not reveal any significance in the main effect. 


\section{Discussion}

A cross-modal lexical priming paradigm (Swinney 1979) allows researchers to measure participants' online activation of lexical, syntactic and semantic information during sentence processing. Unlike other online or offline paradigms, the self-paced reading paradigm for example, which examine explicit responses, cross-modal lexical priming paradigm taps into implicit and automatic online responses. Given its many advantages, a cross-modal priming paradigm has been used in many psycholinguistic studies to tease apart competing theories that have puzzled researchers using other methodologies. For example, examining double object constructions in Greek relative clauses, Paspali \& Marinis (2017) used a cross-modal lexical priming paradigm to examine two competing theories, Trace Reactivation Hypothesis and Direct Association Hypothesis, both of which have been supported by studies using different techniques. Paspali \& Marinis measured participants' responses to pictures of either antecedents of relative clauses or unrelated probes. Their results showed a priming effect only at the offset of the direct object, thus providing support for the base IO-DO word order.

The current study employed this paradigm to examine whether the Unaccusative Hypothesis provides a satisfactory distinction between two kinds of intransitive verbs, that is, unergatives and unaccusatives, which are syntactically represented and semantically determined. According to the Unaccusative Hypothesis, even though these two subclasses have only one argument, which is manifested at the initial position for both types of construction, the syntactic configuration for each type is very different. The major difference between unergative verbs and unaccusative verbs lies in whether the argument is external or internal. The single argument in unergative verbs is external, or preverbal, and does not move from the postverbal position. The single argument in unaccusative verbs, however, is internal or postverbal in the base-generated structure and is moved to the beginning of a sentence. Accordingly, a gap is left when the argument is moved to the beginning of a sentence, leading to filler-gap mapping during sentence processing. When the argument is external, no movement is needed and thus no trace exists for filler-gap dependency.

The results of the current experiment confirmed the above predictions, thus lending support to the Unaccusative Hypothesis. According to this hypothesis, the difference between unaccusative verbs and unergative verbs lies in where their argument originates. For unaccusative verbs, the argument originates from the position behind the verb and then is moved to the beginning of the sentence. If this is true, a trace will be left at the original position and filler-gap mapping is bound to happen at this position. Unergative verbs, however, have external arguments and therefore no movement or filler-gap mapping is involved. The 
results showed that both the non-alternating and alternating Mandarin unaccusative verbs with arguments occurring preverbally showed a V-shaped line, indicating a priming effect elicited by semantic-related probes at the beginning, followed by decay of the effect at the second position and then a reactivation of the antecedent at the third and the fourth position. Even though a priming effect was not observed in the second position, reactivation was observed at the third position and the fourth position. There were faster response times for related probes than unrelated probes at the third positions and this effect was carried over to the fourth position, although the effect was not necessarily as big. The reactivation can be used to suggest that comprehenders were processing filler-gap dependency. When the arguments occurred postverbally, an inverted V-shaped line was observed. No priming effect was found at the first position. Instead, it was found at the second position, which was not too surprising because this was the position for the argument to occur, thus leading to faster response times for the related probes. After the second position, a linear decay line was observed. Results for the unergative verbs did not show any reactivation at all. This result is in line with Friedmann et al's (2008) study. A priming effect was seen at the first position and was followed by decay at the second, third and fourth positions.

As stated in the previous paragraph, there was no immediate reactivation at the target positions (position 2 in both non-alternating and alternating unaccusatives), where the filler-gap mapping was supposed to occur. No immediate reactivation was found in Friedmann et al's study either. In both studies, reactivation was found at the third and fourth position by the current study. As stated previously, one possible reason for the delay of reactivation is because there were no overt wh-words or relative pronouns to let the parser know of an upcoming gap. This also seems to be true in other cross-modal priming studies whose stimuli contained no overt wh-words or relative pronouns. For example, Osterhout \& Swinney (1993) examined priming effects between active sentences (e.g., "The dentist from the new medical center in town invited the actress to go to the party.") and verbal passive sentences (e.g., "The dentist from the new medical center in town was invited $t$ by the actress to go to the party."). Probe points were presented either immediately after the offset of the matrix verb, $500 \mathrm{~ms}$ after the matrix verb, or $1000 \mathrm{~ms}$ after the matrix verb. Note that even though there were no wh-words or relative pronouns in passive constructions, our parser could still be signaled for filler-gap mapping when processing chunks like "was invited" and "by phrase." Nevertheless, a priming effect was not found at the immediate probe point or $500 \mathrm{~ms}$ probe point. The only reliable priming effect was found at the $1000 \mathrm{~ms}$ probe point.

Taken together, the fact that Mandarin unaccusatives allow preverbal and postverbal arguments makes it possible for us to design a more balanced exper- 
iment to tap into implicit reactivation during sentence comprehension. In addition, the use of four trace positions in the current experiment also made it possible to examine the appearance and decay of the priming effect. Even though the results from the current study offer further and clearer pieces of evidence that unaccusative and unergative verbs map their argument onto different positions, this study is not without limitations.

One of the major limitations concerns how related and unrelated probes were chosen. According to Friedmann et al., care was taken to match a related probe and an unrelated probe in terms of the number of letters, number of syllables and word frequency. However, this study did not control for the number of strokes and word frequency in the Mandarin probes because while it is possible to control for word frequency, simultaneously controlling for the number of strokes and word frequency would make the related probes less semantically related. Therefore, word frequency and the number of strokes were not controlled for since keeping the probes semantically related was more important.

\section{Online appendix}

An online appendix is available at: https://doi.org/10.1075/consl.ooo28.lin.appendix

\section{References}

Aldridge, Edith. 2015. Ergativity and unaccusativity. Encyclopedia of Chinese language and linguistics. Retrieved 12 January, 2021, from http://referenceworks.brillonline.com/entries /encyclopedia-of-chinese-language-andlinguistics/ergativity-and-unaccusativity-COM _ooo173

Bever, Thomas G., and Brian McElree. 1988. Empty categories access their antecedents during comprehension. Linguistic Inquiry 19.1:35-43.

Bever, Thomas G., and Montserrat Sanz. 1997. Empty categories access their antecedents during comprehension: Unaccusatives in Spanish. Linguistic Inquiry 28.1:69-91.

Chng, Krystal. Y.T., Melvin J. Yap, and Winston D. Goh. 2019. Cross-modal masked repetition and semantic priming in auditory lexical decision. Psychonomic Bulletin \& Review 26.2:599-608. https://doi.org/10.3758/s13423-018-1540-8

Chung, Taegoo. 2014. Multiple factors in the L2 acquisition of English unaccusative verbs. International Review of Applied Linguistics in Language Teaching 52.1:59-87. https://doi.org/10.1515/iral-2014-0003

Dell, Gary. S., Gail McKoon, and Roger Ratcliff. 1983. The activation of antecedent information during the processing of anaphoric reference in reading. Journal of Verbal Learning and Verbal Behavior 22.1:121-132. https://doi.org/10.1016/So022-5371(83)80010-3

Fadlon, Julie. 2016. The transitive-unaccusative alternation: A cross-modal priming study. Journal of Psycholinguistic Research 45.3:671-696. https://doi.org/10.1007/s10936-015-9368-o 
Friedmann, Naama, Gina Taranto, Lewis P. Shapiro, and David A. Swinney. 2008. The leaf fell (the leaf): The online processing of unaccusatives. Linguistic Inquiry 39.3:355-377. https://doi.org/10.1162/ling.2008.39.3.355

Hickok, Gregory. 1993. Parallel parsing: Evidence from reactivation in garden-path sentences. Journal of Psycholinguistic Research 22.2:239-250.

$\mathrm{Hu}$, Jianhua, and Haihua Pan. 2008. Mandarin intransitive verbs and their objects at the syntax-information structure interface. Proceedings of the 2oth North American Conference on Chinese Linguistics (NACCL-20) Vol. 2, ed. by Marjorie K. M. Chan and Hana Kang, 653-663. Columbus, $\mathrm{OH}$ : The Ohio State University.

Huang, Chu-Ru. 1993. Mandarin Chinese and the lexical mapping theory: A study of the interaction of morphology and argument changing. The Bulletin of the Institute of History and Philology 62:337-388.

Huang, C.-T. James. 1989. Zhongwen de liangzhong jiwu dongci he liangzhong bujiwu dongci [Two kinds of transitive verbs and intransitive verbs in Chinese]. Proceedings of the and World Congress of Chinese Language Studies, ed. by Martin Woesler, 39-59. Taipei: World Chinese Language Association.

Huang, C. -T. James. 2006. Resultatives and unaccusatives: A parametric view. Bulletin of the Chinese Linguistic Society of Japan 253:1-43. https://doi.org/10.7131/chuugokugogaku.2006.1

Ju, Min Kyong. 2000. Overpassivization errors by second language learners: The effect of conceptualizable agents in discourse. Studies in Second Language Acquisition 22.1:85-111. https://doi.org/10.1017/S0272263100001042

Kim, Hyunwoo. 2014. Testing the advanced Korean EFL learners' acquisition of the unaccusative verb in online processing. Journal of the Korea English Education Society 13.2:1-19. https://doi.org/10.18649/jkees.2014.13.2.1

Kim, Sun Hee, Sunyoung Choi, and Jeen Kyoung Kang. 2016. Asymmetry of L2 learners' implicit and explicit knowledge of unpaired English unaccusatives. English Teaching 71.1:47-71.

Levin, Beth, and Malka Rappaport Hovav. 1995. Unaccusativity: At the Syntax-Lexical Semantics Interface. Cambridge, MA: MIT press.

Li, Yen Hui Audrey. 2012. Order and Constituency in Mandarin Chinese. Dordrecht, the Netherlands: Springer Science \& Business Media. (Original work published 1990)

Love, Tracy, and David A. Swinney. 1996. Coreference processing and levels of analysis in object-relative constructions: Demonstration of antecedent reactivation with the crossmodal priming paradigm. Journal of Psycholinguistic Research 25.1:5-24. https://doi.org/10.1007/BFo1708418

Nicol, Janet Lee. 1988. Coreference Processing during Sentence Comprehension. Doctoral dissertation, Massachusetts Institute of Technology, Cambridge.

Nicol, Janet Lee, and David A. Swinney. 1989. The role of structure in coreference assignment during sentence comprehension. Journal of Psycholinguistic Research 18.1:5-19. https://doi.org/10.1007/BF01069043

Nicol, Janet Lee, and Lee Osterhout. 1988. Experimental evidence for the immediate use of subcategorization information during parsing. Unpublished manuscript.

Nicol, Janet Lee, J.D. Fodor, and David A. Swinney. 1994. Using cross-modal lexical decision tasks to investigate sentence processing. Journal of Experimental Psychology: Learning, Memory, and Cognition 20.5:1229-1238.

Oshita, Hiroyuki. 2001. The unaccusative trap in second language acquisition. Studies in Second Language Acquisition 23.2:279-304. https://doi.org/10.1017/So272263101002078 
Osterhout, Lee, and David A. Swinney. 1993. On the temporal course of gap-filling during comprehension of verbal passives. Journal of Psycholinguistic Research 22.2:273-286.

Paspali, Anastasia, and Theodoros Marinis. 2017. Integrating the filler: Evidence from double object constructions in Greek relative clauses. Studies in Greek Linguistics 37:601-614.

Paul, Waltraud, Yaqiao Lu, and Thomas Hun-tak Lee. 2020. Existential and locative constructions in Mandarin Chinese. The Linguistic Review 37.2:231-267. https://doi.org/10.1515/tlr-2019-2043

Perlmutter, David M. 1978. Impersonal passives and the unaccusative hypothesis. Proceedings of the Fourth Annual meeting of the Berkeley Linguistics Society, ed. by Jeri J. Jaeger, Anthony C. Woodbury, Farrell Ackerman, Christine Chiarello, Orin D. Gensler, John Kingston, Eve E. Sweetser, Henry Thompson and Kenneth W. Whistler, 157-190. Berkeley, CA: University of California. https://doi.org/10.3765/bls.v4io.2198

Sorace, Antonella. 1993a. Incomplete vs. divergent representations of unaccusativity in nonnative grammars of Italian. Second Language Research 9.1:22-47. https://doi.org/10.1177/026765839300900102

Sorace, Antonella. 1993b. Unaccusativity and auxiliary choice in non-native grammars of Italian and French: Asymmetries and predictable indeterminacy. Journal of French Language Studies 3.1:71-93. https://doi.org/10.1017/S0959269500000351

Sorace, Antonella. 1995. Acquiring linking rules and argument structures in a second language: The unaccusative/unergative distinction. The Current State of Interlanguage, ed. by Lynn Eubank, Larry Selinker and Michael Sharwood Smith. 153-175. Amsterdam: John Benjamins. https://doi.org/10.1075/z.73.13sor

Sorace, Antonella. 2000. Gradients in auxiliary selection with intransitive verbs. Language 76.4:859-89o. https://doi.org/10.2307/417202

Sorace, Antonella, and Frank Keller. 2005. Gradience in linguistic data. Lingua 115.11:1497-1524. https://doi.org/10.1016/j.lingua.2004.07.002

Sorace, Antonella, and Yoko Shomura. 2001. Lexical constraints on the acquisition of split intransitivity: Evidence from L2 Japanese. Studies in Second Language Acquisition 23.2:247-278. https://doi.org/10.1017/S0272263101002066

Swinney, David A. 1979. Lexical access during sentence comprehension. Journal of Verbal Learning and Verbal Behavior 18.6:645-66o. https://doi.org/10.1016/Soo22-5371(79)90355-4

Swinney, David A., Ford, M., Frauenfelder, U., and Bresnan, J. 1988. On the temporal course of gap-filling and antecedent assignment during sentence comprehension. Language Structure and Processing, ed. by Barbara Grosz, Donald Kaplan, Mark Macken and Ivan Sag, 361-365. Stanford, CA: CSLI Publications.

Tanenhaus, Michael K., Laurie A. Stowe, and Greg Carlson. 1985. The interaction of lexical expectation and pragmatics in parsing filler-gap constructions. Proceedings of the Seventh Annual Cognitive Science Society Meetings, ed. by Richard H. Granger, Jr., 361-365. Seattle, WA: Cognitive Science Society.

Yuan, Boping. 1999. Acquiring the unaccusative unergative distinction in a second language: Evidence from English-speaking learners of L2 Chinese. Linguistics 37.2:275-296. https://doi.org/10.1515/ling.37.2.275

Zaenen, Annie. 1993. Unaccusativity in Dutch: Integrating syntax and lexical semantics. Semantics and the Lexicon, ed. by James Pustejovsky, 129-161. Dordrecht, the Netherlands: Kluwer Academic Publishers. https://doi.org/10.1007/978-94-011-1972-6_9 Zhou, Xinping. 1990. Aspects of Chinese Syntax: Ergativity and Phrase Structure. Doctoral dissertation, University of Illinois at Urbana-Champaign, Champaign. 


\section{Address for correspondence}

Yowyu Lin

Department of Foreign Languages and Literatures

National Taiwan University

Taipei, TAIWAN

brianlin@ntu.edu.tw

\section{Publication history}

Date received: 14 December 2020

Date revised: 19 March 2021

Date accepted: 7 June 2021 